\title{
Diseases, prophylaxis and treatment of the Atlantic halibut Hippoglossus hippoglossus: a review
}

\author{
Øivind Bergh*, Frank Nilsen, Ole B. Samuelsen \\ Institute of Marine Research, Department of Aquaculture, PO Box 1870 Nordnes, 5817 Bergen, Norway
}

\begin{abstract}
After substantial investments in research, the Atlantic halibut Hippoglossus hippoglossus is now being cultivated commercially in Norway, Iceland, Scotland and Canada. As with other domesticated species, disease problems have been experienced. This review summarizes the current state of knowledge of diseases of the Atlantic halibut, and their diagnosis, prophylaxis and treatment. In economic terms, the most important losses have been suffered at the larval and juvenile stages. The most important infections are caused by nodaviruses, causative agents of Viral Encephalopathy and Retinopathy (VER), which are the major reason why Norway's production of halibut fry has been level since 1995. An aquatic birnavirus, Infectious Pancreatic Necrosis Virus, is also an important agent of mortality. Vibrio anguillarum, Flexibacter ovolyticus and atypical Aeromonas salmonicida are the major bacterial pathogens. The protozoan parasites recorded include Ichthyobodo sp., the microsporidium Enterocytozoon sp., Trichodina hippoglossi, and the metazoan pathogens include myxozoans, helminths, Entobdella hippoglossi, Lepeophtheirus hippoglossi and other parasitic copepods. Experimental vaccines have been tested against $V$. anguillarum and atypical A. salmonicida, with good results. A recombinant vaccine against nodaviruses is under development. A few trials have been carried out on non-specific immunostimulants, but no such treatment is currently available. A number of efficacy and pharmacokinetic trials with various antibacterial agents have also been published.
\end{abstract}

KEY WORDS: Atlantic halibut · Diseases · Prophylaxis · Treatment

\section{INTRODUCTION}

During the late 1980s and the 1990s, substantial efforts have been made in several countries to bring the Atlantic halibut Hippoglossus hippoglossus into commercial aquaculture (reviewed by Mangor-Jensen et al. 1998b). The natural habitat of the halibut is the waters of the North Atlantic Ocean and the Norwegian Sea (Haug 1990). It was therefore thought that the natural conditions off the coasts of Norway, Scotland, Iceland and Canada would be favourable for the spe-

*E-mail: oivind.bergh@imr.no cies (Tilseth et al. 1990). Following the commercial success of the salmon industry in Norway and Scotland, and due to its high price, well-established markets, and its natural presence in cold waters, the halibut seemed to be a good candidate for aquaculture in Northern Europe and Canada.

The domestication of a new species inevitably involves disease control, and there is no doubt that this has also been experienced in halibut aquaculture, for a number of reasons. The high host density in aquaculture gives parasitic organisms a competitive ecological advantage compared to the natural situation. Secondly, suboptimal rearing conditions resulting from attempts to cultivate organisms whose biology is largely 
unknown may accidentally compromise the defence systems of the host. Thirdly, disease conditions that may be common among wild fish are largely unrecognised by humans. However, in aquaculture systems the fish farmer will recognise signs of disease such as reduced growth, abnormal behaviour and increased mortality, all of which rapidly call for attention by veterinarians and scientists.

The main challenge experienced by halibut farms has been to achieve adequate survival rates, particularly during the early life stages. Thus, since the early 1990s, the amount of experience and knowledge of diseases of viral, bacterial or parasitical etiology of the Atlantic halibut has grown significantly. The evidence for the importance of diseases that affect the early life stages, such as infections by birnaviruses (Biering et al. 1994), nodaviruses (Grotmol et al. 1995, 1997), or various opportunistic bacteria (Bergh et al. 1992b) has now been demonstrated by different challenge experiments (Table 1).

The parasite fauna of wild Atlantic halibut have not been widely studied, for which reason our knowledge

Table 1. Microbial pathogens known to cause mortality in experimental challenge studies with different developmental stages of Atlantic halibut. IPNV: Infectious Pancreatic Necrosis Virus

\begin{tabular}{|c|c|c|}
\hline Ontogenetic stage & Pathogen & Source \\
\hline $\begin{array}{l}\text { Eggs and } \\
\text { yolk-sac larvae }\end{array}$ & $\begin{array}{l}\text { Flexibacter ovolyticus } \\
\text { Vibrio anguillarum } \\
\text { V. salmonicida } \\
\text { V. splendidus }\end{array}$ & Bergh et al. (1992b) \\
\hline $\begin{array}{l}\text { Eggs and } \\
\text { yolk-sac larvae }\end{array}$ & $\begin{array}{l}\text { Aeromonas salmonicida subsp. } \\
\text { salmonicida }\end{array}$ & Bergh et al. (1997) \\
\hline $\begin{array}{l}\text { Eggs and } \\
\text { yolk-sac larvae }\end{array}$ & $\begin{array}{l}\text { F. ovolyticus } \\
\text { ( } 3 \text { different strains) } \\
\text { A. salmonicida subsp. } \\
\text { salmonicida } \\
\text { V. anguillarum }\end{array}$ & Bergh (2000) \\
\hline $\begin{array}{l}\text { Weaned fry } \\
(0.1,1.0 \text { and } 3.5 \mathrm{~g})\end{array}$ & IPNV & Biering et al. (1994) \\
\hline Yolk-sac larvae & IPNV & Biering \& Bergh (1996) \\
\hline Subadults & $\begin{array}{l}\text { A. salmonicida } \\
\text { subsp. salmonicida } \\
\text { Atypical A. salmonicida }\end{array}$ & Bricknell et al. (1999) \\
\hline Yolk-sac larvae & $\begin{array}{l}\text { Nodavirus } \\
\text { (halibut strain) }\end{array}$ & Grotmol et al. (1999) \\
\hline Fry $(15 \mathrm{~g})$ & Atypical A. salmonicida & Ingilæ et al. (2000) \\
\hline Fry $(<5 \mathrm{~g})$ & V. anguillarum & Samuelsen (1997) \\
\hline Fry $(<5 \mathrm{~g})$ & V. anguillarum & Samuelsen et al. (1997a) \\
\hline Yolk-sac larvae & $\begin{array}{l}\text { V. anguillarum } \\
\text { F. ovolyticus }\end{array}$ & Skiftesvik \& Bergh (1993) \\
\hline Yolk-sac larvae & $\begin{array}{l}\text { Nodavirus } \\
\text { (halibut strain) } \\
\text { (striped jack strain) }\end{array}$ & Totland et al. (2000) \\
\hline
\end{tabular}

of potential harmful parasites in farmed fish is limited. Studies of parasites on wild halibut have mainly concentrated on describing metazoan parasites, particularly helminths (e.g. Polyanskii 1955, Scott \& Bray 1989). Furthermore, all these studies were performed on larger halibut (from $29 \mathrm{~cm}$ length upwards) and there are no published data on parasites on wild halibut fry.

In aquaculture, parasites with a direct life cycle have the greatest potential to be causative agents of diseases. The low occurrence or absence in aquaculture of intermediate hosts needed for transmission for many groups of parasites excludes parasites with more complicated life cycles. However, the production of marine fish normally requires the use of zooplankton as start feed. By using wild-caught zooplankton, potential intermediate hosts are introduced as feed for the larvae. Several groups of common parasites are transmitted through zooplankton, including the digenea, cestoda, nematoda and acatocephala. Most of these parasites show a low degree of pathogenity to larger fish but larvae and fry are considerably more vulnerable.

The objective of this paper is to provide an overview of the various diseases of Atlantic halibut, including reports on prophylactic and therapeutic procedures used to control these diseases.

\section{COMMERCIAL HALIBUT PRODUCTION}

Apart from some pioneering experiments by Rollefsen (1934), who reported successful hatching of halibut eggs in his laboratory, the first attempts to rear Atlantic halibut, larvae for aquacultural purposes were made in Norway between 1974 and 1980 (Blaxter et al. 1983). As a result, the first 2 metamorphosed fry were produced in 1980 in floating plastic bags at Flødevigen Research Station, Arendal, Norway. This stimulated a research programme on halibut cultivation in Norway, which was followed by similar programmes in the UK, Iceland and Canada (Mangor-Jensen et al. 1998b).

Trial commercial production of the Atlantic halibut is currently underway in these 4 countries (Fig. 1). In 1999 the total production of fry in Norway was estimated at 346000 individuals, 


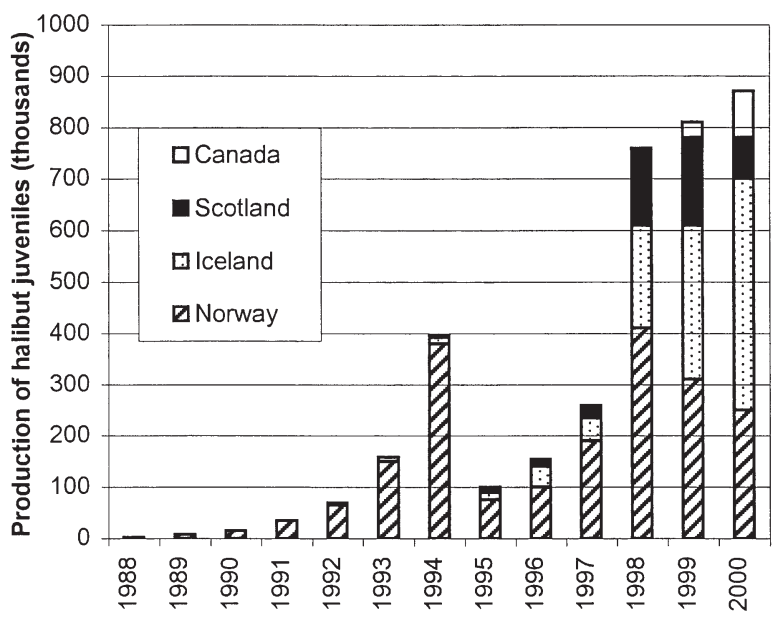

Fig. 1. Hippoglossus hippoglossus. Annual production of individuals of juvenile Atlantic halibut in Norway, Iceland, Scotland and Canada 1988-2000. Data extracted from van der Meeren (2000) and the NUMARIO programme of the Norwegian Research Council

in Iceland 350 000, in Scotland 170000 and Canada 48000 (van der Meeren 2000). According to information from halibut farmers, the production in 2000 increased in Iceland to 450000 and in Canada to 90000 , whereas the Norwegian and Scottish production of juveniles decreased to 250000 and 80000 , respectively. It can be assumed mortalities due to infectious diseases, particularly aquatic birnaviruses and nodaviruses, explains much of the decrease in the production in Norway, and probably Scotland. While 14 different hatcheries were currently in operation in Norway, efforts in the other 3 countries appear to be more focused, with 1 major hatchery in each country. While Norwegian fry production is still dominated by semi-intensive technology (reviewed by van der Meeren \& Naas 1997), the other countries focus sharply on intensive techniques. In particular, the good results achieved by intensive techniques at the single hatchery in Iceland, Fiskeldi Eyafjardar hf, suggest that such production strategies will dominate in the future. Interestingly, the major disease problems, particularly nodaviruses, that have compromised Norwegian halibut production, have not yet been reported from Iceland so far, a factor which may explain part of the steady growth in Icelandic halibut production.

\section{PRINCIPLES OF ATLANTIC HALIBUT AQUACULTURE}

The halibut is a multiple spawner that may release as many as 15 batches of eggs during the spawning season (Norberg et al. 1991). Although natural spawning may occur in captivity, the usual method entails stripping eggs and milt from ripe broodstock, followed by artificial fertilization (Mangor-Jensen et al. 1998a). Halibut eggs are transparent and naturally buoyant at a salinity of 32 to $34 \mathrm{ppt}$. Eggs are normally reared in upwelling incubators, with a plankton net to prevent them from being drained out at the overflow. The optimum water temperature limits are relatively narrow at 5 to $7^{\circ} \mathrm{C}$. The eggs hatch approximately 82 daydegrees after fertilization when incubation temperatures are kept within these limits (Mangor-Jensen et al. 1998a). Seasonally independent egg and fry production has been achieved for halibut by the photoperiod manipulation of broodstock (Næss et al. 1996).

At hatching, the larva is at a primitive ontogenetic stage (Pittman et al. 1990b). The eyes are poorly developed, and electron microscopic observations have shown that the retina does not become functional until 150 degree-days after hatching (Kvenseth et al. 1996). Light is not a critical factor for normal morphogenesis of the retina of halibut to the time of first feeding (Helvik \& Karlsen 1996), and yolk-sac larvae are therefore typically reared in darkness. The mouth and anus are not open at hatching, and the only access from the environment to the intestine is through the pseudobranches (Pitttman et al. 1990b). This is probably the route of entry for the first bacteria that colonise the intestine, as the halibut has a well-established intestinal flora even before active feeding commences (Bergh 1995).

The duration of the yolk-sac stage, i.e. the time from hatching until the larva has developed sufficiently to start exogenous feeding, is extremely long for halibut, varying from 30 to $50 \mathrm{~d}$, depending on temperature. Due to the length of the yolk-sac stage, specialised incubators for yolk-sac larvae have been developed. Yolk-sac larvae are typically reared as described by Harboe et al. (1994b) in large-scale upwelling silos ranging in volume from 5 to $10 \mathrm{~m}^{3}$ in Norway, Iceland and Canada, whereas smaller rearing tanks $(0.5$ to $1.5 \mathrm{~m}^{3}$ in volume) have been adapted for use in the UK (Shields et al. 1999). Temperature is typically kept at 5 to $6^{\circ} \mathrm{C}$, which is consistent with the findings of Pittman et al. (1990a) that larvae kept at $6^{\circ} \mathrm{C}$ had higher survival and lower mortality rates than larvae kept at 3 or $9^{\circ} \mathrm{C}$. However, the temperature is now often gradually increased towards the onset of feeding. Like the eggs, the yolk-sac larvae are relatively sensitive to changes in salinity, as their normal condition is to be neutrally buoyant. It is therefore common practice to alter the salinity of the inlet water if necessary (Mangor-Jensen et al. 1998b).

First feeding of halibut is carried out by means of various procedures. The extensive or semi-intensive approaches use naturally occurring zooplankton, but 
these have shown lack of stability and control (reviewed by van der Meeren \& Naas 1997). Variable weather conditions and the limited supplies of natural zooplankton have resulted in the unpredictability of production. Furthermore, this aquaculture concept is only feasible in northern countries during the summer months. In order to exploit the seasonally independent production of fertilised halibut eggs achieved by photoperiod-manipulated broodstock, other approaches are necessary (Næss et al. 1996), and the development of intensive approaches has been initiated.

Harboe et al. (1998) describe a typical tank design for first feeding of halibut by the intensive approach. A knowledge of larval behavioural responses to light regimes has proved to be particularly critical. High initial larval mortality has been the normal pattern during first feeding (Naas et al. 1992, 1995, 1996, Harboe et al. 1994a). However, the combination of the addition of algae to the rearing water and the use of UV-A illumination has to some extent improved this situation (Harboe et al. 1998). The roles of microalgae in early feeding are not clearly understood, although ingestion has been reported (Reitan et al. 1994). It was suggested by Naas et al. (1992) that the nutritional effects of the algae are of minor importance in comparison with their effect on physical parameters, in particular light regime. This hypothesis is partially supported by the finding of Bergh et al. (1994) that the shift from a nonfermentative towards a fermentative intestinal bacterial microflora occurred faster in larvae in water to which algae had been added than in larvae kept in water without algal addition.

Intensive first feeding of halibut is based on Artemia spp. as live-feed organisms. Because halibut larva are large, rotifers are generally not used (Mangor-Jensen et al. 1998b). The results of van der Meeren's (1995) energy model of larval feed requirements indicate that the early findings of poor growth among Artemia-fed halibut larvae may have been a result of inadequate feed levels, which probably contributed to the susceptibility to disease. However, it has been demonstrated that high survival and growth rates can be achieved using feeding regimes based only on Artemia, provided that prey consumption rates are sufficiently high (Gara et al. 1998, Harboe et al. 1998), although subsequent problems with metamorphosis of larvae has been frequently observed (Pittman et al. 1998).

Weaning and ongrowth of halibut take place in landbased systems, although trials with sea cages are promising. Apart from parasites, and an apparently high sensitivity to solar radiation (S. Tuene \& Ø. Bergh unpubl. results), which could easily be dealt with by covering the tanks or lowering the sea-cages, only minor disease problems have been reported on subadult and adult halibut.

\section{AQUATIC BIRNAVIRUSES}

The halibut is susceptible to infections by an aquatic birnavirus, Infectious Pancreatic Necrosis Virus (IPNV), and several outbreaks of disease have been reported from Norwegian halibut hatcheries since 1989 (Mortensen et al. 1990). Aquatic birnaviruses are widespread in the marine environment, and IPNV is abundant in Atlantic salmon Salmo salar farms in Norway (Melby et al. 1991). Only minor sero- and genotypic differences were found between 3 Norwegian isolates from halibut and the N1 strain from Atlantic salmon (Biering et al. 1997). Furthermore, isolates from salmonids have been found to establish an infection in halibut (Biering 1997b), so that transfer of virus between salmon and halibut cannot be excluded. There is reason to believe that IPNV is widespread in Norwegian halibut stocks (Biering 1997b), captive as well as wild.

On the basis of challenge experiments with halibut fry (Biering et al. 1994) and yolk-sac larvae (Biering \& Bergh 1996) it has been concluded that the virus is the cause of the disease. Temperature influenced mortality, as fry challenged at $15^{\circ} \mathrm{C}$ had significantly higher mortality than fry challenged at $12^{\circ} \mathrm{C}$ (Biering et al. 1994). The authors also found that susceptibility to IPNV was related to developmental stage, as smaller fry tended to be more susceptible to infection. Fry with a mean weight of $0.1 \mathrm{~g}$ suffered significantly higher mortality than controls when challenged at $12^{\circ} \mathrm{C}$, whilst fry with a mean weight of $1.0 \mathrm{~g}$ did not suffer mortality when infected at this temperature. However, when challenged at $15^{\circ} \mathrm{C}$, the mortality of the fry with a mean weight of $1.0 \mathrm{~g}$ was high. Fry with a mean size of $3.5 \mathrm{~g}$ suffered relatively low, but significant, mortality when infected at $15^{\circ} \mathrm{C}$. Larger fish are probably not severely affected by IPNV infections, but they respond to challenge with a strong humoral immune response (Biering 1997a).

The most characteristic clinical signs of disease in challenged fish are a distended stomach, uncoordinated swimming and trailing, and white faecal casts (Biering et al. 1994). The symptoms were most prominent in small fry, but were also observed in larger individuals. Pathological findings included focal necroses of the liver, kidney and intestine, but the pancreatic tissue was unaffected. Affected hepatocytes were usually hypertrophic, with a large nucleus with condensed chromatin. Sloughing, degeneration and necrosis of the epithelial cells were observed throughout the gut. In the kidney, areas of degeneration and necrosis of the haematopoietic tissue were frequently observed. Immunostaining with a polychlonal anti-IPNV rabbit antiserum revealed viral antigens in the livers of challenged individuals. In the kidney, some large mono- 
nuclear cells, possibly macrophages, were also antigen positive, whereas the pancreatic tissue was negative. The absence of pathological findings in pancreatic tissue of challenged fish reported by Biering et al. (1994) was in disagreement with the findings from naturally infected halibut fry (Mortensen et al. 1990), who found severe necrosis of the pancreatic acinar cells, together with nuclear pyknosis.

The intestine may be the primary organ for virus entry and replication, as suggested by the simultaneous observation of necrosis of the intestinal mucosa with positive immunostaining, and a negative or only slightly positive liver and kidney in several individuals in a challenge experiment with yolk-sac larvae (Biering \& Bergh 1996). However, these authors also pointed out that there are differences in pathology and susceptibility to IPNV infection at different developmental stages. As IPNV by definition causes necrosis of the pancreas, which is a condition not always found in affected halibut, the term aquatic birnavirus is probably more correct (Biering et al. 1994).

\section{NODAVIRUSES}

Nodaviruses, a family of neuropathogenic viruses first described from insects, are known to cause infections and disease in more than 19 marine fish species in many parts of the world (reviewed by Munday \& Nakai 1997). The disease, now termed Viral Encephalopathy and Retinopathy (VER), was first recorded in halibut in the summer of 1995, when 2 major hatcheries in Western Norway were severely affected (Grotmol et al. 1995, 1997). Most larvae died in the period of early metamorphosis, approximately 60 to $70 \mathrm{~d}$ posthatch. The pattern of mortality was typical of an acute outbreak and most fish died within a week of the onset of mortality.

As described by Grotmol et al. (1997), the clinical signs of VER first seen in the larvae were reduced skin pigmentation and empty, transparent intestines resulting from reduced food intake. In juvenile fish, darkening of the skin was seen. Abnormal behaviour such as spiral swimming and looping was observed in the early stages of a disease outbreak. Severely diseased larvae and juveniles became lethargic, often lying upside down on the bottom. Occasionally, tonic spasms of the myotomal musculature could be observed, resulting in temporary flexion of the body. Light microscopy examination revealed lesions in the retina, brain and spinal cord, and in ganglia of the peripheral nervous system, with no lesions detected in other organs. Large vacuoles were exclusively located in the amacrine cells within the bipolar nuclear layer and in the neurons of the ganglionic layer. Specific immunostaining was obtained in affected organs. Electron microscopy revealed both extra- and intracellular virus particles in affected tissues.

The nodavirus strain from halibut is able to replicate and cause VER in halibut yolk-sac larvae following experimental challenge (Grotmol et al. 1999). Monitoring the progression of the infection following challenge suggested that the portal of entry into the larvae may have been the intestinal epithelium, while the route of infection to the central nervous system (CNS) may have been axonal transport to the brain stem through cranial nerves such as the vagus nerves. Later in the infection, lesions became more severe and widespread and were also found throughout the epithelium, gills and pectoral fins.

Nodaviruses recovered from different fish species have been shown to possess genetic differences (Nishizawa et al. 1997). Comparing the pathogenicity of a strain from halibut (AH95NorA) and a strain from striped jack Pseudocaranx dentex, Totland et al. (2000) found that the halibut strain, which caused high mortality in halibut larvae, was unable to replicate or cause disease in striped jack larvae, and vice versa. It could not be determined, however, whether this difference was the result of host specificity or of the difference in rearing temperature $\left(6^{\circ} \mathrm{C}\right.$ for halibut and $20^{\circ} \mathrm{C}$ for striped jack). On the basis of sequencing of the capsid protein gene, Grotmol et al. (2000) demonstrated that nodavirus strains that affect cold-water species are closely related, belonging to a separate clade, whereas nodavirus strains that affect temperate fish species, including the striped jack strain (SJ92Nag), belonged to other clades.

The diagnosis of nodavirus infections in halibut has so far been dependent on histological and immunostaining procedures (Grotmol et al. 1997, 1999). An RT-PCR assay based on the capsid protein nucleotide sequence of the halibut nodavirus strain has been developed (Grotmol et al. 2000). Using an optimised RT-PCR technique, Nerland et al. (A. Nerland, Institute of Marine Research Norway, pers. comm.) have demonstrated the potential for horizontal transmission of nodavirus during an outbreak, by detecting presence of the virus in the rearing water. However, vertical transmission also occurs, and may be blocked by ozone disinfection of eggs (Grotmol \& Totland 2000).

VER may be the most important disease problem in halibut aquaculture today. The outbreak in Norway coincides with a decline in halibut fry production, and is probably the most important reason why Norway's production of halibut fry has been level since 1995. No vaccine is currently available, although the development of a vaccine has been initiated using the turbot Scophthalmus maximus as an animal model (Húsgarð et al. 2001). Outbreaks of VER in halibut, however, 
tend to occur at relatively early ontogenetic stages and before vaccination would be possible. Therefore, it has been suggested that immunization of the female broodstock fish with subsequent transfer of antibodies to the yolk of the eggs may have to be adopted as a prophylactic measure in the future. At present, we are left with traditional prophylactic countermeasures, such as egg surface disinfection and improved hygiene.

\section{BACTERIAL DISEASES}

As in other marine fish, the early life stages of the halibut are susceptible to opportunistic bacteria. The mucosal surfaces of eggs and larvae are colonised by bacteria, some of which are pathogens. From field studies, Vibrio spp. are frequently isolated (Bolinches \& Egidius 1987). Isolates of $V$. anguillarum from marine fish with vibriosis, including halibut, were found to be free of plasmids, strongly indicating that their virulence properties were chromosome-mediated (Wiik et al. 1989).

Bacteria are found in large numbers on the surface of halibut eggs. This epiflora seems to be dominated by members of the Cytophaga/Flavobacterium/Flexibacter group, whereas Vibrio spp. are less frequent (Hansen \& Olafsen 1989, Bergh 1995). The composition of the intestinal bacterial flora associated with yolk-sac larvae resembles the egg epiflora, whereas a shift in the intestinal microflora from a generally nonfermentative towards a fermentative flora dominated by the Vibrio/Aeromonas group coincides with the onset of exogenous feeding (Bergh et al. 1994, Bergh 1995).

The psychrophilic bacterium Flexibacter ovolyticus was isolated from halibut eggs that had suffered high mortality rates (Hansen et al. 1992). It resembles the fish pathogen Flexibacter maritimus, but differs from the latter in a number of biochemical and physiological characteristics. Challenge experiments confirmed that this bacterium is capable of causing mortality in halibut eggs and yolk-sac larvae by penetrating the eggshell (Bergh et al. 1992b). It has not been found on hosts other than halibut, despite its ability to cause mortality in the eggs and larvae of cod Gadus morhua (Bergh 2000). It should be noted that $F$. ovolyticus, according to 16SrRNA similarities, belongs to a cluster of marine isolates that includes $F$. maritimus, and that it has been suggested by Bernardet et al. (1996) that the entire group has been wrongly classified. However, the species name Flexibacter ovolyticus is still currently used.

Several species of Vibrio cause mortality in yolk-sac larvae. V. anguillarum, V. splendidus and a V. salmonicida-like strain were tested in a challenge experiment by Bergh et al. (1992b). The strain resembling V. salmonicida was shown by 16 SrRNA analysis to be closely related to $V$. salmonicida strains isolated from Atlantic salmon suffering from cold-water vibriosis (Wiik et al. 1995). Unlike F. ovolyticus, the Vibrio spp. did not result in egg mortality, but infected the larvae posthatch, causing mortality during the yolk-sac stage. Of these species, $V$. anguillarum, serotypes $\mathrm{O} 1$ and $\mathrm{O} 2 \mathrm{a}$ were the most virulent, whereas the others must be present in relatively large numbers in order to cause significant mortality (Bergh unpubl. results). Challenge experiments with $V$. anguillarum serotype $\mathrm{O} 1$ on weaned halibut fry confirm that this bacterium is also pathogenic to later life stages of halibut (Samuelsen 1997, Samuelsen et al. 1997a)

Opportunistic bacteria affecting yolk-sac larvae typically induce changes in larval behaviour, reducing the ability of the larva to initiate exogenous feeding, and decreasing the buoyancy of the larva (Skiftesvik \& Bergh 1993). Thus, even though the opportunists may not kill the larva directly, the probability of survival to the first feeding period may be reduced. In an upwelling incubator as described by Harboe et al. (1994b), a larva with decreased buoyancy would inevitably sink; thus, the inlet seawater will pass through a zone of moribound larvae before it reaches the healthy larvae.

The causative agent of furunculosis in Atlantic salmon, Aeromonas salmonicida subsp. salmonicida is for most practical purposes avirulent to halibut. In a field survey during a major outbreak of furunculosis in the Atlantic salmon stock at the Austevoll Aquaculture Research Station in 1990, all dead halibut at the station were subjected to investigation (Hjeltnes et al. 1995), but no indications of a transfer of the bacterium were found. An experimental challenge with typical A. salmonicida subsp. salmonicida administered to yolk-sac larvae had more complex results (Bergh et al. 1997). Although there was significant mortality, this probably resulted from the production of extracellular toxins produced by the bacterium, as histological and immunostaining examinations of the larvae revealed no evidence of bacteria in affected tissues.

In contrast to the Aeromonas salmonicida subsp. salmonicida, which comprises a homogeneous group of strains, atypical A. salmonicida strains are heterogeneous with respect to serological and biochemical characteristics (Wiklund \& Dalsgaard 1998). However, atypical strains of A. salmonicida are occasionally isolated from diseased halibut suffering from septicaemia, but the possibility cannot be ruled out that some of these infections may be secondary. Recently, however, Ingilæ et al. (2000) reported significant mortality in a challenge experiment with an atypical strain isolated from halibut and administered to halibut of approximately $15 \mathrm{~g}$.

Comparing the pathogenicity of one atypical and one typical strain of Aeromonas salmonicida to subadult halibut (weight range 154 to $254 \mathrm{~g}$ ), Bricknell et 
al. (1999) found no mortality as a result of bath challenge. Minimum lethal doses per halibut after intraperitoneal injection of bacterium were $10^{6}$ (typical $A$. salmonicida) and $10^{7}$ (atypical A. salmonicida). A stress test of the survivors following the challenge showed that while 9 of the 87 halibut died, all were culture negative for A. salmonicida, suggesting that no carrier state had been established.

\section{MICROSPORIDIA}

Microsporidia are obligate intracellular parasites that are known from a wide range of host taxa (Canning \& Lom 1986). Fish are a common host group and a wide range of species has been described (Canning \& Lom 1986). Most species of microsporidia in fish are believed to be transmitted directly from host to host, although this remains to be experimentally demonstrated for many species. Their intracellular nature and direct transmission route turn microsporidia into harmful pathogens in aquaculture. To date, 2 species of microsporidia have been reported from farmed Atlantic halibut (Nilsen \& Bristow 1994, Nilsen et al. 1995). Nilsen \& Bristow found infections by a microsporidium in the muscle of halibut larvae. In heavily infected larvae the infections appeared systemic and spores were observed in various internal organs. As the main target tissue was skeletal muscle they suggested that the species involved might belong to the Pleistophora, as this is the main target tissue for these species. However, Nilsen et al. (1998) have recently obtained genetic evidence that muscle-infecting microsporidia in fishes are a polyphyletic group and the generic position of the species reported by Nilsen \& Bristow (1994) thus remains uncertain.

Nilsen et al. (1995) reported an intranuclear microsporidium from lymphoblasts of farmed Atlantic halibut. Infected cells were found in the anterior kidney and in heavy infections more than $50 \%$ of the lymphoid cells contained the intranuclear microsporidium (see Fig. 2). Infected fish had an enlarged and swollen posterior kidney and splenomegaly. Histological changes included degeneration of tubules and eaematopoietic tissue. On the basis of morphology and ultrastructure Nilsen et al. (1995) identified the species in halibut as belonging to Enterocytozoon. A similar intranuclear microsporidium, Nucleospora salmonis, has been reported from Oncorhynchus spp. (Hedrick et al. 1990, Chilmonczyk et al. 1991). This species was originally classified as E. salmonis but Docker et al. (1997) stated that the correct generic name is Nucleospora. Furthermore, genetic data support the view that the fish microsporidium is sufficiently genetically distant from the type species of Enterocytozoon (i.e. E. bieneusi from the human intestine) for it to be placed in a separate genus (Docker et al. 1997, Nilsen 2000). N. salmonis and the intranuclear microsporidia from Atlantic halibut are morphologically very similar, and recent studies comparing ribosomal genes suggest that the microsporidium found in halibut is most likely to be a Nucleospora species (Gresoviac et al. 2000). No data concerning the mode of infection exist for the Nucleospora species from halibut. Studies on N. salmonis in chinook salmon have demonstrated that this species is transmitted directly from fish to fish (Baxa Antonio et al. 1992). In vitro studies have also provided evidence for immunodepression of both the B- and T-cell functions of $N$. salmonis-infected lymphocytes from chinook salmon (Wongtavatchai et al. 1995). More studies are needed in order to determine whether the Nucleospora species that infects Atlantic halibut has similar effects.

\section{TRICHODINIDS}

One of the most common groups of ectoparasites comprises species belonging to the family Trichodinidae. Trichodinids have a direct lifecycle and high host densities in fish farms facilitate transmission. Trichodina spp. are found on the skin and gills of a wide range of fish species (Lom \& Dykova 1992). Infection levels are normally low in wild fish and trichodinids are often regarded as harmless commensals. However, under farming conditions high levels of infection can occur, with subsequent mortality if they are left untreated. Nilsen (1995) described Trichodina hippoglossi from the skin of farmed Atlantic halibut fry. The species is large, with a clear central circle in silverstained specimens. High infection levels occurred when the temperature was raised to $15^{\circ} \mathrm{C}$ and above. Infections occur regularly in farms and treatment with formalin is required.

\section{ICHTHYOBODO SP.}

The ectoparasitic flagellate Ichthyobodo necator (=Costia necatrix) has long been known to be a pathogen of freshwater fish (e.g. Lom \& Dykova 1992). Infections on marine fishes with a similar flagellate (Ichthyobodo sp.) have recently been reviewed by Urawa et al. (1998). According to Urawa et al. (1998) Ichthyobodo have been found in 25 species of marine fish, including Atlantic halibut. Rødseth (1995) was the first to report Ichthyobodo infections in farmed Atlantic halibut. Later, unverified reports from farmers and veterinarians have been communicated, and we have recently obtained histological samples from farmed halibut infected by Ichthyobodo (Fig. 2). Infections are 


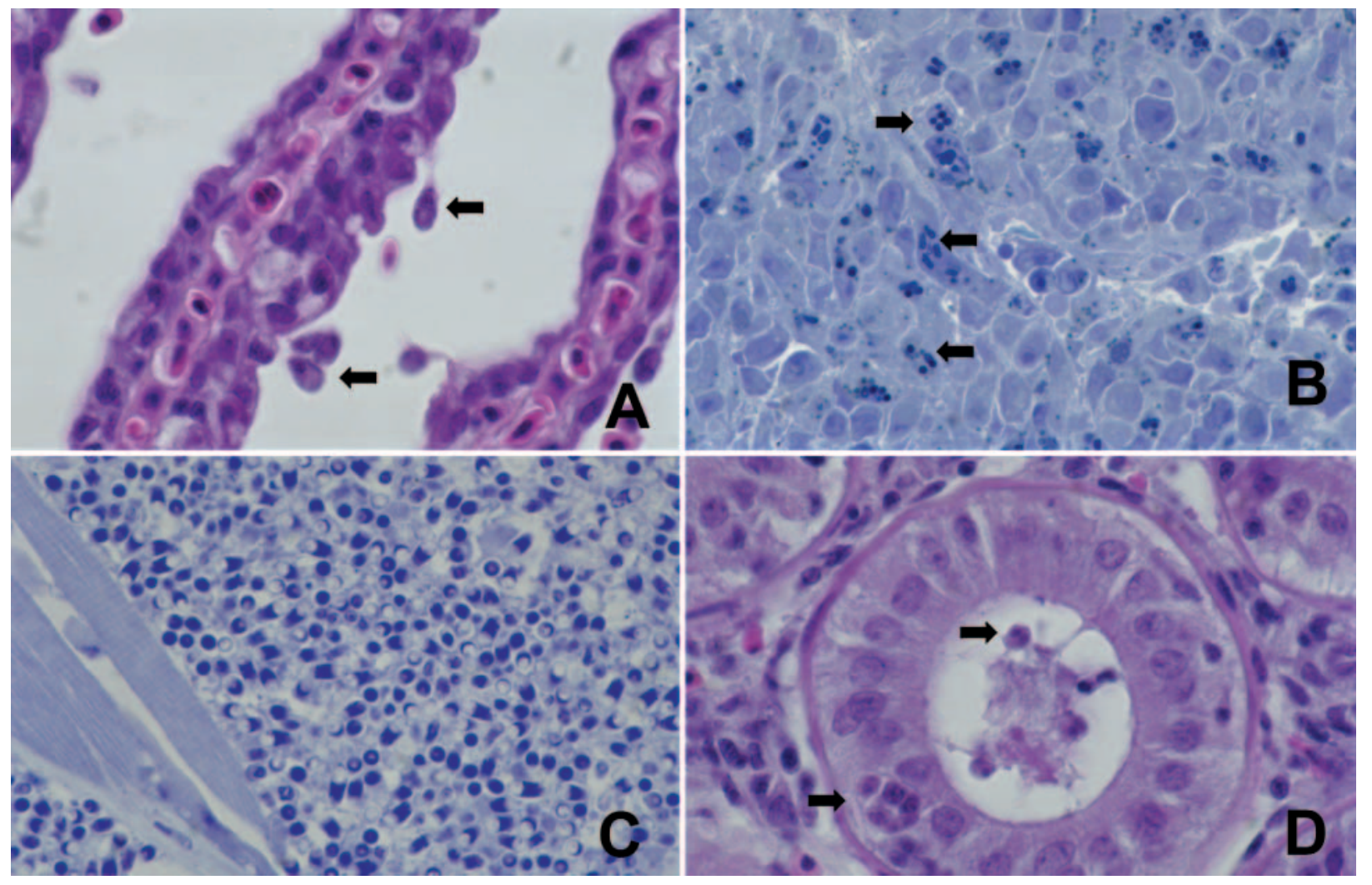

Fig. 2. Hippoglossus hippoglossus. (A) Section through halibut gill showing Ichthyobodo sp. (arrows) attached to the secondary lamellas. (B) Histological section through head kidney of Atlantic halibut infected with Nucleospora sp. Intranuclear inclusions with pre-sporogonic developmental stages and spores (arrows) in the lymphoblasts. More than $50 \%$ of the cells are infected by Nucleospora sp. (C) Histological section from the skeletal muscle of halibut larvae showing large amounts of microsporidium spores. Note the prominent posterior vacuole. (D) Section from the kidney of juvenile Atlantic halibut. Chloromyxum-like myxosporidium spores are evident in the tubular lumen (arrow) and developmental stages occurred between the tubular cells (arrow)

normally identified by loss of appetite, changes in behaviour and the appearance of a greyish skin colour. Generally, marine forms of Ichthyobodo have a preference for the gills, while $I$. necator typically parasitises the skin and fins. The parasite is transmitted directly from host to host, and aquaculture conditions, with their high host densities, facilitate transmission. Infections with Ichthyobodo spp. normally require treatment and formalin has been widely used.

\section{MYXOZOA}

The myxosporidia are multicellular microparasites that mainly infect fish (Lom \& Dykova 1992). Experimental studies have shown that this group of parasites requires an intermediate host, normally an annelid, to complete its lifecycle. It has recently been shown that bryozoa act as an intermediate host for certain myxozoans (Anderson et al. 1999). Several species are known to produce severe diseases in both wild and famed fish (see Lom \& Dykova 1992). Different species of myxosporidia infect a wide range of host tissues and pathogenicity seems to be related to tissue tropism. Lom \& Dykova (1992) listed 3 species of myxosporidia that have been recorded in Atlantic halibut. Ceratomуха drepanopsettae, Leptotheca sp. and Myxidium sphaericum all infect the gall bladder. Morrison et al. (1996) recorded C. drepanopsettae in 7 of 8 wild-caught Atlantic halibut. Histological study did not reveal any particular pathology associated with the infections. There are no published records of myxosporidia from farmed Alantic halibut. However, histological examination of kidneys of farmed juvenile halibut has revealed the occurrence of a Chloromyxum-like myxosporidian in the kidney tubules (see Fig. 2).

\section{HELMINTH INFECTIONS}

With the exception of monogenetic trematodes, all helminths have an indirect lifecycle that requires one 
or more intermediate hosts. The ecology of wild Atlantic halibut results in a broad parasitic fauna, particularly of endoparasitic helminths (F. Nilsen pers. obs.). However, these parasites have to be introduced to the halibut through an intermediate host. Under farming conditions, this can be controlled to a large extent by avoiding infected food organisms such as natural zooplankton. In the early days of halibut farming, wild zooplankton was widely used as a start food, leading to infections by various helminth species (Bristow 1990). The use of Artemia as the sole or dominant live-feed organisms in many hatcheries has reduced or eliminated the problem of food-introduced parasites, although it has also increased problems of malpigmentation (Næss \& Lie 1998).

The particular species that may be introduced by wild zooplankton seems to vary from farm to farm, depending on the parasite fauna in the local zooplankton. A study of helminth parasites from a Norwegian Atlantic halibut hatchery revealed 3 different species (F. Nilsen unpubl. data). Two digenean (Hemiurus luehei and Derogenes varicus) and one nematode (Hysterothylacium aduncum) species were frequently recorded in halibut larvae and fry (unpubl. data). The 2 digenean species occurred in the stomach and intestine while the nematode species was typically found in the viscera. The most frequent species was $H$. luehei, of which up to 6 specimens were recorded in a single larvae. The significance of infections by $H$. luehei is unclear but high infection levels will probably result in impaired digestion and clogging of the intestine, followed by lower survival rates. Survival of halibut larva in the different start-feeding batches was also related to the number of helminths recorded and the batch with the highest infection produced an unexpectedly low number of metamorphosed fry.

The nematode Hysterothylacium aduncum occurred as L-3 larvae in the viscera of halibut larvae and fry. This species uses fish as both second intermediate host and final host (Køie 1993). Typically, in small fish it occurs in the form of 3rd stage larvae in the buccal cavity. In the study mentioned above, a striking observation was that we never recorded more than one specimen of $H$. aduncum in individual halibut fry or larvae and there was also a higher frequency of this species in the dead fish. The number of fish examined fish was high (over 600 specimens) and if $H$. aduncum occurred by chance one would expect that infections with more than one larva would occur at a low frequency. A possible explanation is that infections by more than one $H$. aduncum were lethal for the halibut at this stage and, hence, that halibut with double infections died and were removed undiscovered from the population.
Bristow (1990) found 4 different helminth parasites in halibut larvae and fry. In addition to the species mentioned above, Bristow recorded a cestod larva (plerocercoides) in the intestine. Bristow claimed that these helminths were responsible for up to $80 \%$ of the mortality of halibut larvae and fry.

\section{MONOGENIC TREMATODES}

This group of helminths generally act as ectoparasites on fish. A typical feature is a very high degree of host specificity, and most species infect only one host species. All have a direct lifecycle, a feature which increases their potential as pathogens under aquaculture conditions. The majority of species produce eggs that are released to the seabed. The ciliated oncomirracidium larva is infectious for the fish. Entobdella hippoglossi is specific for Atlantic halibut, in which it infects the fins and skin. E. hippoglossi has been recorded on farmed Atlantic halibut, mainly on larger specimens, where it can cause harm if concentrations are sufficiently high. Treatment is necessary in order to remove the parasite efficiently. Svendsen \& Haug (1991) tested the effecacy of formalin, benzocain and hypo- and hypersalinity on E. hippoglossi adults and eggs. Adult worms survived formalin treatment (200 ppm). Exposure to 80 ppm benzocain resulted in a rapid detachment of the parasite and parasites were also effectively killed by exposure to hypersaline $(4 \%)$ and freshwater. In practice, only benzocain is useful, but only if the detached parasites are removed after treatment. The eggs are very resistant to treatment and they may attach to the tank after they are released from the females. Hot freshwater decreased the proportion of hatching eggs but some eggs hatched under all the tested conditions (Svendsen \& Haug 1991). The recommended procedure to remove the parasite from an infected tank is to conduct repeated treatments before the second generation of E. hippoglossi has started to produce eggs.

\section{PARASITIC CRUSTACEA}

A large number of parasitic copepods have been described from marine fish by Kabata (1979), who listed 6 species of parasitic copepods recorded on Atlantic halibut (Caligus curtus, C. minimus, Hatschekia hippoglossi, Lepeophtheirus hippoglossi, L. pectoralis and Neobrachiella rostrata), of which two were uncertain records (C. minimus and L. pectoralis). Parasitic copepods are potentially important pathogens in fish farms due to their direct lifecycle, without the need of an intermediate host. 


\section{Lepeophtheirus hippoglossi}

The primary host for Lepeophtheirus hippoglossi is Atlantic halibut and there are only a few reports from other host species (Kabata 1979). This species is easily distinguished from other Lepeophtheirus spp. by its sternal furca with bifid tines (Kabata 1979). Schram \& Haug (1988) examined wild-caught Atlantic halibut (size range 35 to $250 \mathrm{~cm}$ ) for ectoparasites. The only copepod species they recorded was L. hippoglossi. They found a clear correlation between host size and occurrence of L. hippoglossi, where the largest hosts had the highest prevalence and intensity. The lifecycle of L. hippoglossi has recently been elucidated (Armstrong et al. 1999); it is similar to the salmon louse $L$. salmonis. The lifecycle is comprised of 3 free-living stages (2 nauplius stages and 1 copepodite stage) 4 chalimus stages and pre-adult and adult stages. Its generation time at 7 to $8^{\circ} \mathrm{C}$ was approximately $8 \mathrm{wk}$. Armstrong et al. (1999) found that adult females survived for up to $71 \mathrm{~d}$ and produced up to 7 pairs of egg strings, with an average of 134 eggs pair $^{-1}$. Large haemorrhagic lesions were found on the experimentally infected halibut. The intensity of the parasite was as low as 25 preadults per halibut (fish size approximately $1 \mathrm{~kg}$ ). This report indicates that $L$. hippoglossi is a potentially important pathogen in Atlantic halibut farms.

\section{Caligus spp.}

Like most of the Lepeophtheirus spp., Caligus spp. infect the skin and fins of marine fish species. The most extensively studied species is $C$. elongatus, a species with a broad range of hosts, which has been reported from more than 80 different species (Kabata 1979). The lifecycle of $C$. elongatus is similar to L. salmonis with the exception that $C$. elongatus lacks the pre-adult stages (Piaseki \& McKinnon 1995). Kabata (1979) listed Atlantic halibut as one of the hosts for C. curtus but, so far, this species has not been recorded on farmed halibut. However, C. elongatus has been recorded on farmed Atlantic halibut with high intensity (F. Nilsen pers. obs.). Halibut (approximately $500 \mathrm{~g}$ ) were reared in net pens and during the summer they were heavily infected by $C$. elongatus (more than 100 specimens halibut $^{-1}$ ). Most of the parasites were located in the head region, causing severe lesions. Treatment with organophosphates removed the parasites efficiently.

\section{Hatschekia hippoglossi}

Hatschekia hippoglossi is specific to Atlantic halibut (Kabata 1979), where it is attached to the gills.
According to Kabata, this species is most frequently recorded on small halibut, and he found a prevalence of $26.9 \%$ on Atlantic halibut from 29 to $63 \mathrm{~cm}$ (age 2 to $5 \mathrm{yr}$ ). The morphology of Hatschekia shows a specialisation to a parasitic lifestyle with a reduction in the number of body segments and appendages (Kabata 1979). Very little is known about its lifecycle and to the best of the authors' knowledge no experimental studies on the lifecycle have been published. There are no reports on this species from farmed Atlantic halibut.

\section{Neobrachiella rostrata}

This species is also specific to the Atlantic halibut, where it is reported to infect the gills and also the pseudobranch (Kabata 1979). Very little is known about the biology of this species and there are no reports on it from farmed halibut.

\section{GAPING JAW}

The gaping jaw syndrome has been described by Pittman et al. (1990b). In larvae with this condition, the oral membrane is missing, and the cartilages of the jaws appear to be locked open, so that the mouth cannot be closed voluntarily. The consequence is an inability to feed, inevitably leading to death when the absorption of the yolk sac is complete.

In an extensive morphological study Morrison \& MacDonald (1995) demonstrated that the jaws of these larvae were not disarticulated, but the anterior parts of the ethmoid and Meckel's cartilages were bent apart. These authors suggested that the development of gaping jaws appears to be related to abrasion of the skin of the head through contact with the rearing container, and to penetration of the eroded tissues by opportunistic organisms present in the water. This could partly explain the observation by Harboe et al. (1994a) that the larval groups from disinfected egg batches had a significantly higher frequency of feeding larvae than non-disinfected groups. In general, the incidence of gaping-jaw larvae increases with increasing temperature (Pittman et al. 1989, 1990a), an environmental factor that might cause increased bacterial activity and increase larval swimming activity. However, it should be noted that the gaping jaw condition is not related to the total number of bacteria in the rearing water (Opstad \& Bergh 1993). Likewise, an increased incidence of gaping jaw has not been the result of experimental challenge by known bacterial pathogens such as Vibria anguillarum, V. spendidus, V. salmonicida, Flexibacter ovolyticus or Aeromonas salmonicida 
subsp. salmonicida (Bergh et al. 1992b, 1997). The exact nature of the gaping jaw syndrome remains unresolved.

\section{VACCINATION AND NON-SPECIFIC IMMUNOSTIMULATION}

Studies of vaccination, immunisation or immunostimulation of halibut are few and far between. Recently, Ingilæ et al. (2000) demonstrated protection in challenge experiments of halibut vaccinated intraperitoneally with oil-emulsified vaccines against atypical Aeromonas salmonicida. High antibody titres were produced and the major antibody response was against the A-layer of the bacterium. Bath and aqueous-based injection vaccines failed to protect the fish against the disease when they were bath-challenged 10 wk postvaccination. As in the case of salmon, however, there are indications that adjuvants appear to induce potentially detrimental adhesions (Bowden et al. 2000).

Many of the important diseases of Atlantic halibut, such as VER and infections with Flexibacter ovolyticus, primarily affect relatively early life stages. Vaccination of fish larvae at immunologically immature ontogenetic stages may induce immunosuppression rather than protection (Joosten et al. 1995), and can therefore not be recommended. Recent data indicate that the lymphoid organs, i.e. the thymus and kidney, develop, and immunoglobulin-bearing cells proliferate, around the time of first feeding (Bergh et al. unpubl.), whereas the spleen could not be found before well into exogenous feeding. Vaccination before this stage may therefore be impossible. However, there are indications that weaned halibut at a size of $0.1 \mathrm{~g}$ can be vaccinated against vibriosis ( $\varnothing$. Bergh unpubl. data).

Stimulation of the non-specific immune system is an alternative method, which could be suitable for earlier ontogenetic stages. Vadstein et al. (1993) exposed yolk-sac larvae to the macrophage stimulator FMI (alginate rich in mannuronic acid) in a small-scale experiment. They observed survival rates of 31 to $79 \%$ and 0 to $29 \%$ respectively, for the groups with and without addition of FMI, but no attempts were made to verify that stimulation of the macrophage system was the reason for the differences observed. It must also be noted that survival rates in all groups could be regarded as poor. Another immunomodulator, laminaran $(\beta(1,3)$-glucan), was administered via water to halibut yolk-sac larvae by Strand \& Dalmo (1997), who demonstrated that uptake was limited to the epithelial layers of the intestine and skin. However, a laboratory study demonstrated that the addition of laminaran did not improve survival throughout the yolk-sac stage (Dalmo et al. 2000), the authors explaining the results in terms of the bacterial degradation of laminaran. The search for an effective immunostimulant which would be more resistant to bacterial degradation led Dalmo et al. $(1998,2000)$ to the bacterial lipopolysaccharide, LPS, obtained from cultures of Aeromonas salmonicida subsp. salmonicida. LPS is an interesting candidate as an immunostimulant, since it is an important constituent of vaccines based on killed bacteria, and has been shown to activate fish macrophages and B-cells in vitro and in vivo after injection. LPS was taken up by the larvae, but confined to intestinal epithelial cells, the lumen of the excretory duct and numerous cells in the epidermal layer. Groups of larvae were exposed to $12.5,25,50$ and $100 \mu \mathrm{g} \mathrm{LPS} \mathrm{ml}{ }^{-1}$. Survival was significantly improved in comparison with untreated larvae in the groups with the 2 highest LPS concentrations (Dalmo et al. 2000). Although the results are promising, development of a protocol for immunostimulation of early developmental stages of halibut suitable for the production scale must still be regarded as being in an early phase.

\section{PROBIOTICS}

The application of so-called probiotic bacteria, i.e. live microbial food additives that improve the composition of the intestinal microflora (Fuller 1989) has gained increased attention in aquaculture in recent years (reviewed by Gatesoupe 1999). Bergh (1995) demonstrated the presence of bacteria in the intestine of halibut with the ability to inhibit growth of a pathogenic Vibrio sp. Using Artemia franciscana as a vector, we were able to demonstrate uptake of such strains in the intestine of halibut larvae by means of immunohistochemical staining (Ø. Bergh unpubl. data). However, it must be noted that the growth inhibiting capability of the intestinal strains is unstable in culture (S. Jensen \& Ø. Bergh unpubl. results).

\section{PHARMACOKINETICS}

In combination with minimum inhibitory concentration (MIC) examinations and clinical efficacy investigations, the study of the pharmacokinetic properties of drugs is an important tool for the establishment of optimal dosage regimes, and thus the promotion of their correct use in treatments. Furthermore, in fish species destined for human food species, the establishment of correct withdrawal times is based on knowledge of the elimination rate of the drugs from tissues. As the pharmacokinetic properties of antibacterial agents may vary significantly from species to species, the disposition of a drug should be investigated in the particular 
species in which it is intended to be used (Kleinow et al. 1994, Martinsen et al. 1994, van der Heiden 1994).

The range of antibacterial agents available to fish farmers is limited. At present, 6 antibacterial agents are used in aquaculture in Norway; the quinolones flumequine and oxolinic acid, the tetracycline derivative oxytetracycline, the potentiated sulphonamide Tribrissen (trimetoprim + sulphadiazine) and florfenicol which is an amphenicol derivative. Antibacterial agents are usually administered as medicated food pellets, with the antibacterial either coated on the surface of the pellets using a small quantity of oil or incorporated into the pellet. In some circumstances, antibacterials may be administered by bath or by intraperitoneal injection.

A number of studies have addressed the pharmacokinetics of antibacterial agents in Atlantic salmon held in seawater (Rogstad et al. 1993, Elema et al. 1994, 1995, Martinsen \& Horsberg 1995), whereas pharmacokinetic information on antibacterials in Atlantic halibut is limited.

Using bath treatment for $72 \mathrm{~h}$, the absorption and excretion of the quinolones flumequine and oxolinic acid, 4 sulphonamides and trimethoprim were studied in small (<5 g) Atlantic halibut (Samuelsen \& Lunestad 1996, Samuelsen et al. 1997a). The temperature in the baths was $12^{\circ} \mathrm{C}$. Sulphadimidine obtained the highest tissue concentrations of the 4 sulphonamides and was therefore chosen as the companion sulphonamide to trimetoprim. It was suggested that the difference in sulphonamide concentrations was primarily due to variations in the ability of Atlantic halibut to metabolise the sulphonamides to the N-4 acetylated derivative, and less importantly, to differences in absorption. Using a combination of $500 \mathrm{mg} \mathrm{l}^{-1}$ sulphadimidine and $100 \mathrm{mg} \mathrm{l}^{-1}$ trimethoprim in the bath, peak muscle and liver concentrations of 262 and $312 \mu \mathrm{g} \mathrm{g}^{-1}$ were obtained for sulphadimidine and 32.8 and $83.6 \mathrm{\mu g} \mathrm{g}^{-1}$ for trimethoprim (Samuelsen et al. 1997a). In muscle the elimination half-lives were 98 and $35 \mathrm{~h}$ respectively for trimethoprim and sulphadimidine, with corresponding values of 116 and $48 \mathrm{~h}$ in liver. Bath treatment using $150 \mathrm{mg} \mathrm{l}^{-1}$ of flumequine and $200 \mathrm{mg} \mathrm{l}^{-1}$ of oxolinic acid produced flumequine concentrations of $14.2 \mathrm{\mu g} \mathrm{g}^{-1}$ in muscle and $85.4 \mathrm{\mu g} \mathrm{g}^{-1}$ in an abdominal organ homogenate. Corresponding values for oxolinic acid were 9.4 and $72.6 \mu \mathrm{g} \mathrm{g}^{-1}$. The excretion of both antibacterials was rapid and characterised by elimination halflives $\left(t_{1 / 2} \beta\right)$ of 10 and $15.6 \mathrm{~h}$ respectively for flumequine and oxolinic acid in muscle and 9.8 and $15.0 \mathrm{~h}$ respectively in the abdominal organ homogenate.

Pharmacokinetic examinations in large Atlantic halibut include single-dose studies of orally (p.o.), intraperitoneally (i.p.) and intravenously (i.v.) administered oxolinic acid and oral administration of an oxolinic acid ester (vetoquinol). The fish varied in weight from 1.5 to $3 \mathrm{~kg}$ and the studies were performed in seawater at $9^{\circ} \mathrm{C}$ (Samuelsen \& Ervik 1999). Bioavailability after i.p. injection was 92 versus $15 \%$ after administration of oxolinic acid as medicated feed (p.o.). Oral administration of oxolinic acid in the form of the carbitol ester (vetoquinol) raised the bioavailability of oxolinic acid from 15 to $64 \%$ and the total bioavailability (oxolinic acid + vetoquinol) to $82 \%$. Peak plasma concentration $\left(C_{\max }\right)$ of oxolinic acid increased from 2.1 to $6.7 \mu \mathrm{g} \mathrm{ml}^{-1}$ while time to peak plasma concentration $\left(T_{\max }\right)$ fell from 21.5 to $6.3 \mathrm{~h}$ following administration of vetoquinol compared to oxolinic acid. A distribution volume, $V_{\mathrm{dss}}$ of $3.0 \mathrm{l} \mathrm{kg}^{-1}$ suggests wide distribution of oxolinic acid through the tissues. Unexpected results were the large bioavailability (92\%) and prolonged $T_{\max }$ value $(80 \mathrm{~h})$ following i.p.-injection of the drug. Elimination half-lives $\left(t_{1 / 2} \beta\right)$ of oxolinic acid in plasma were not influenced by the administration route and were calculated at 52, 48, 42 and $50 \mathrm{~h}$ respectively following i.v., p.o (given as oxolinic acid), p.o. (given as vetoquinol) or i.p. administrations. The authors concluded that oral administration of oxolinic acid produced lower bioavailability in Atlantic halibut than in Atlantic salmon and that vetoquinol enhanced pharmacokinetic properties such as $C_{\max }, T_{\max }$ and bioavailability compared to administration of oxolinic acid. Therefore, improved clinical efficacy following the administration of vetoquinol should be expected.

Flumequine was studied in Atlantic halibut following p.o. administration using medicated feed (25 mg $\mathrm{kg}^{-1}$ ) and i.p. (25 $\left.\mathrm{mg} \mathrm{kg}^{-1}\right)$ and i.v. $\left(10 \mathrm{mg} \mathrm{kg}^{-1}\right)$ injections (Samuelsen \& Ervik 1997). The fish varied in weight from 1.5 to $2.5 \mathrm{~kg}$ and the temperature was $9^{\circ} \mathrm{C}$. Bioavailabilities of $31 \%$ (p.o.) and $69 \%$ (i.p.) were obtained. The oral administered group had a $C_{\max }$ of $2.7 \mu \mathrm{g} \mathrm{ml}^{-1}$ at $T_{\max } 20 \mathrm{~h}$ whereas the i.p.-injected group had a $C_{\max }$ of $6.1 \mu \mathrm{g} \mathrm{ml}^{-1}$ at $T_{\max } 10 \mathrm{~h}$. The plasma $t_{1 / 2} \beta$ was calculated to be $43 \mathrm{~h}$ for the i.v.-injected group. The distribution volume, $V_{\mathrm{dss}}$ of $2.3 \mathrm{l} \mathrm{kg}^{-1}$ is slightly lower than that of oxolinic acid. Despite a lower p.o. bioavailability, the authors concluded that the pharmacokinetic properties of flumequine in Atlantic halibut were not dramatically different from those in Atlantic salmon. They also commented on the large difference in elimination half-lives calculated for large and small Atlantic halibut and suggested that pharmacokinetic data obtained using small fish cannot be directly extrapolated to larger fish (Samuelsen \& Lunestad 1996, Samuelsen \& Ervik 1997). Less than $10 \mathrm{ng} \mathrm{ml}^{-1}$ of the metabolite 7 -hydroxy-flumequine was found in the plasma samples of Atlantic halibut. This is in agreement with the results of van der Heiden et al. (1994), who found only traces of this metabolite in plasma samples of common carp Cyprinus carpio, 
African catfish Clarias gariepinus and European eel Anguilla anguilla.

Atlantic halibut with a mean weight of $89 \pm 15 \mathrm{~g}$, held in seawater at $10.3^{\circ} \mathrm{C}$ were dosed with flumequine by intravenous injection and via oral administration in feed $\left(10 \mathrm{mg} \mathrm{kg}^{-1}\right)$ (Hansen \& Horsberg 1999). Bioavailability following oral administration was $56 \%$ and plasma $t_{1 / 2} \beta$ values were 32 and $43 \mathrm{~h}$ respectively, following i.v. and p.o. administration. The p.o. group reached a $C_{\max }$ of $1.4 \mathrm{\mu g} \mathrm{ml}^{-1}$ at a $T_{\max }$ of $7 \mathrm{~h}$. The distribution volume was $2.99 \mathrm{l} \mathrm{kg}^{-1}$.

Employing bath treatment for $2 \mathrm{~h}$ and a concentration of $10 \mathrm{mg} \mathrm{l}^{-1}$ of flumequine in the bath, the mean plasma concentration was calculated to be $0.08 \mathrm{\mu g} \mathrm{ml}^{-1}$ and bioavailability to be $5 \%$ (Hansen \& Horsberg 1999). The authors concluded that a higher concentration of the drug in the bath and a prolonged treatment regime are needed to obtain therapeutic concentrations.

Samuelsen \& Lunestad (1996) and Samuelsen et al. (1997a) present data on the elimination times of antibacterial agents in Atlantic halibut. The elimination time $\left(E_{\mathrm{t}}\right)$ is defined as the time for the intercept of the regression line and the Maximum Residue Limit (MRL) concentration of the drugs. The MRL values for trimethoprim and sulphadimidine in fish are 0.05 and $0.1 \mathrm{\mu g} \mathrm{g}^{-1}$, respectively. Calculated $E_{\mathrm{t}}$ values for trimethoprim and sulphadimidine were 49 and $22 \mathrm{~d}$ respectively in liver and 34 and $15 \mathrm{~d}$ respectively in muscle. The authors concluded that although the calculations were derived from data obtained using small Atlantic halibut and direct extrapolation must be made with caution, the results indicated withdrawal times for sulphadimidine and trimethoprim in Atlantic halibut in general agreement with the suggested withdrawal times for Atlantic salmon.

Calculated $E_{\mathrm{t}}$ values were 6.5 and $8 \mathrm{~d}$ respectively for flumequine and oxolinic acid in muscle and 7.5 and $9 \mathrm{~d}$ respectively in abdominal organ homogenate when a maximum residue concentration of $0.05 \mathrm{\mu g} \mathrm{g}^{-1}$ was employed for both drugs. No elimination times for drug residues have been determined for large Atlantic halibut.

\section{EFFICACY}

Injection into the intraperitoneal cavity or muscle is the most effective and accurate method of administering an antibacterial agent to individual fish. However, individual injection is very time-consuming and is mainly used to treat valuable broodstock fish. Administration of antibacterials via bath treatment is independent of the feeding behaviour of the fish and may be an alternative means of treating small fish in a limited volume of water.
The treatment of fish with antibacterial agents incorporated in feed is intended to control the level of infection in the group rather than infections in individual fish. Since loss of appetite is frequently observed in those fish that are suffering from a bacterial disease, oral treatment of a population will mainly deliver the drug to those individuals that are still relatively healthy. The treatment may therefore be considered prophylactic rather than therapeutic inasmuch as it aims to prevent further amplification and spread of an existing infection.

Several papers on the efficacy of antibacterials in treating bacterial infections in Atlantic salmon have been published (Michel et al. 1980, Austin et al. 1983, Stoffregen et al. 1993, Elston et al. 1995, Samuelsen et al. 1997b, Nordmo et al. 1998). Only a few, however, deal with this topic in Atlantic halibut. In vivo efficacy of the quinolones oxolinic acid and flumequine and of a combination of sulphadimidine and trimethoprim were demonstrated against experimentally induced vibriosis (Vibrio anguillarum) in small Atlantic halibut maintained at $12^{\circ} \mathrm{C}$ and bath-treated for $72 \mathrm{~h}$ (Samuelsen 1997, Samuelsen et al. 1997a). The concentrations in the baths were $100 \mathrm{mg} \mathrm{l}^{-1}$ (trimethoprim), $150 \mathrm{mg} \mathrm{l}^{-1}$ (flumequine), $200 \mathrm{mg} \mathrm{l}^{-1}$ (oxolinic acid) and $500 \mathrm{mg} \mathrm{l}^{-1}$ (sulphadimidine). Initiating treatment with the antibacterials at Day 1 postchallenge resulted in $13 \%$ cumulative mortality in both the quinolone-treated groups, $40 \%$ cumulative mortality in the potentiated sulphonamide group and 93\% cumulative mortality in the unmedicated control groups. When the initiation of medication (flumequine) was postponed to Day 2, 3 or 5 postchallenge, final cumulative mortality rates were 46,60 and $66 \%$ respectively compared to a cumulative mortality of $80 \%$ in the unmedicated control group. The authors point out the importance of starting medication as early as possible. This treatment is not suitable for use in sea cages.

\section{SURFACE DISINFECTION OF EGGS}

Prophylactic treatment of eggs with a disinfectant has been shown to improve both egg survival rates and to decrease the percentage of deformed larvae (Bergh et al. 1991, 1992a, Harboe et al. 1994a, Bergh \& Jelmert 1996, Salvesen et al. 1997). In principle, this prophylactic treatment establishes a hygiene barrier between the rearing water of the broodstock fish, including ovarian fluid, and the rearing water of the larvae, by killing extraovulary organisms. Epibiotic bacteria grow on the surface of halibut eggs (Hansen \& Olafsen 1989), and some of them may be pathogens (Bergh et al. 1992b, Hansen et al. 1992). By killing the epiflora, 
their ability to accumulate to a level which may be harmful to the eggs is blocked, and the possibility that certain species of epiflora may infect the larvae posthatch is avoided.

Evaluating various chemicals as egg surface disinfectants on 3 marine fish species, including halibut, Salvesen \& Vadstein (1995) concluded that glutaraldehyde at concentrations of 400 to $600 \mathrm{mg} \mathrm{l}^{-1}$ and with contact times of 5 to $10 \mathrm{~min}$ had good bactericidal effects without any documented negative effects on eggs and larvae. Using concentrations of 400 and $800 \mathrm{mg} \mathrm{l}^{-1}$ of glutaraldehyde in the baths and a treatment regime for the eggs of $10 \mathrm{~min}$ at $400 \mathrm{mg} \mathrm{l}^{-1}$ or $2.5 \mathrm{~min}$ at $800 \mathrm{mg} \mathrm{l}^{-1}$, Harboe et al. (1994a) found no significant difference in survival or number of deformed larvae between the groups in the yolk-sac period. However, a significant higher survival rate was found during start feeding in the groups of larvae originating from eggs exposed to $400 \mathrm{mg} \mathrm{l}^{-1}$ of the disinfectant for $10 \mathrm{~min}$. In an investigation by Salvesen et al. (1997), Atlantic halibut eggs were treated with glutaraldehyde at concentrations of 400 to $1200 \mathrm{mg} \mathrm{l}^{-1}$ and contact times of 2.5, 5 and 10 min. The best effects on the viability of the yolk-sac larvae were obtained with concentrations between 400 and $800 \mathrm{mg} \mathrm{l}^{-1}$ and contact times of 5 and $10 \mathrm{~min}$. Furthermore, better synchronised hatching was observed in the treated than in the untreated groups. The positive effect was most pronounced on egg batches of poor quality.

Bergh \& Jelmert (1996) treated eggs and larvae of Atlantic halibut with various concentrations of the iodophor Buffodine for $10 \mathrm{~min}$ and at different developmental stages ( $4 \mathrm{~h}$ to $12 \mathrm{~d}$ ) following fertilisation. Both the stage at which the eggs were treated and the concentration of the disinfectant were found to have an effect on survival. The highest numbers of normal larvae were obtained when the eggs were disinfected using a $1 \%$ Buffodine solution on Day 9 after fertilisation. However, the increase in the number of normal larvae relative to untreated controls varied among the different egg batches. The authors therefore concluded that due to variations in the presence of pathogenic micro-organisms among egg batches, surface disinfection with Buffodine is an adequate procedure but divergences in the effect of the treatment must be expected.

Due to severe outbreaks of VER in Norwegian halibut farms, the development of hygiene barriers that are effective against this pathogen is regarded as vital by some researchers and fish farmers. From Japanese studies it is known that disinfection of seawater by ozonation is efficient against nodaviruses and other marine viruses, including IPNV, whereas aldehydes have low efficacy against viral pathogens (Arimoto et al. 1996). In a recent experimental study, Grotmol \&
Totland (2000) exposed eggs to nodavirus and then to ozonated seawater $4 \mathrm{~d}$ before hatching. None of the larvae from virus-exposed eggs washed with ozonated seawater developed VER, which was detected in all the dead larvae from eggs exposed to nodavirus but not washed with ozonated seawater. In the untreated control group about $20 \%$ of the dead larvae had developed VER, indicating that the large-scale facility from which the halibut eggs were taken was already contaminated with nodavirus. The egg groups treated with $4 \mathrm{mg} \mathrm{O}_{3} \mathrm{l}^{-1}$ for $0.5 \mathrm{~min}$ or with lower total ozone exposures had a higher survival rate, and no adverse effects on the development of the larvae after hatching were observed. However, although a slight delay in hatching was observed, after $2 \mathrm{~d}$ the cumulated hatching had normalized. In egg groups with higher total exposures ( $4 \mathrm{mg} \mathrm{O}_{3} \mathrm{l}^{-1}$ for $1 \mathrm{~min}$ or higher total ozone exposures) a pronounced negative effect on hatching was observed. The results are promising, indicating that ozone disinfection can be an efficient hygiene barrier in halibut aquaculture, and several fish farms have adopted the method. In a recent study using ozone, the disinfection of inlet water with subsequent detoxification by thiosulfate was included. Tentative results indicate improved survival of eggs, yolk-sac larvae and fry (G. Totland pers. comm. 2000).

\section{LITERATURE CITED}

Anderson CL, Canning EU, Okamura B (1999) Molecular data implicate bryozoans as hosts for PKX (Phylum Myxozoa) and identify a clade of bryozoan parasites within the Myxzoa. Parasitology 119:555-561

Arimoto M, Sato J, Maruyama K, Mimura G, Furusawa I (1996) Effect of chemical and physical treatments on the inactivation of striped jack nervous necrosis virus (SJNNV). Aquaculture 143:15-22

Armstrong PJ, Sommerville C, Wootten R (1999) The lifecycle of the caligid copepod Lepeophtheirus hippoglossi (Krøyer, 1837) and its pathology on the cultured Atlantic halibut (Hippoglossus hippoglossus L.). In: 5th International Symposium on Fish Parasites. České Budějovice, 9-13 August 1999, p 6

Austin B, Rayment J, Alderman DJ (1983) Control of furunculosis by oxolinic acid. Aquaculture 31:101-108

Baxa Antonio D, Groff JM, Hedrick RP (1992) Experimental horizontal transmission of Enterocytozoon salmonis to chinnok salmon, Oncorhynchus tshawytscha. J Protozool 39:699-702

Bergh Ø (1995) Bacteria associated with early life stages of halibut, Hippoglossus hippoglossus L., innhibit growth of a pathogenic Vibrio sp. J Fish Dis 18:31-40

Bergh $\varnothing ~(2000)$ Bacterial pathogens associated with early life stages of marine fish. In: Bell CR, Brylinski M, JohnsonGreen P (eds) Microbial biosystems: new frontiers. Proc 8th Int Symp Microb Ecol. Atlantic Canada Society for Microbial Ecology, Halifax, p 221-228

Bergh Ø, Jelmert A (1996) Iodophor disinfection of eggs of Atlantic halibut. J Aquat Anim Health 8:135-145

Bergh Ø, Hansen GH, Jelmert A, Skiftesvik AB, Taxt RE 
(1991) Bacterial diseases of eggs and yolk sac larvae of halibut (Hippoglossus hippoglossus L.). In: Lavens P, Sorgeloos P, Jaspers E, Ollevier F (eds) European Aquaculture Society, Spec Publ No. 15, Ghent, Belgia 1991, p 389-391

Bergh Ø, Hansen GH, Huse I, Jelmert A (1992a) Studies on diseases of cultured juvenile Atlantic halibut (Hippoglossus hippoglossus L.). NOAA Tech Rep NMFS 111

Bergh Ø, Hansen GH, Taxt RE (1992b) Experimental infection of eggs and yolk sac larvae of halibut, Hippoglossus hippoglossus L. J Fish Dis 15:379-391

Bergh Ø, Naas KE, Harboe T (1994) Shift in the intestinal microflora of Atlantic halibut (Hippoglossus hippoglossus) larvae during first feeding. Can J Fish Aquat Sci 51(8): 1899-1903

Bergh Ø, Hjeltnes B, Skiftesvik AB (1997) Experimental infection of turbot, Scophtalmus maximus and halibut Hippoglossus hippoglossus yolk sac larvae with Aeromonas salmonicida subsp. salmonicida. Dis Aquat Org 29:13-20

Bernardet JF, Segers P, Vancanneyt M, Berthe F, Kersters K, Vandamme P (1996) Cutting a gordian knot: emended classification and description of the genus Flavobacterium, emended description of the family Flavobacteriaceae, and proposal of Flavobacterium hydatis nom. Nov. (Basonym, Cytophaga aquatilis Strohl and Tait 1978). Int J Syst Bacteriol 46(1):126-148

Biering E (1997a) Immune response of the Atlantic halibut (Hippoglossus hippoglossus L.) to infectious pancreatic necrosis virus (IPNV). Fish Shellfish Immunol 7:137-149

Biering E (1997b) Infectious pancreatic necrosis virus infections of farmed Atlantic halibut (Hippoglossus hippoglossus). Dr Sci thesis, Department of Fisheries and Marine Biology, University of Bergen

Biering E, Bergh $\varnothing$ (1996) Experimental infection of Atlantic halibut, Hippoglossus hippoglossus L., yolk-sac larvae with infectious pancreatic necrosis virus: detection of virus by immunohistochemistry and in situ hybridization. J Fish Dis 19:405-413

Biering E, Nilsen F, Rødseth OM, Glette J (1994) Susceptibility of Atlantic halibut Hippoglossus hippoglossus to infectious pancreatic necrosis virus. Dis Aquat Org 20:183-190

Biering E, Melby H, Mortensen S (1997) Sero- and genotyping of some marine aquatic birnavirus isolates form Norway. Dis Aquat Org 28:169-174

Blaxter JHS, Danielssen D, Moksness E, Øiestad V (1983) Description of the early development of the halibut Hippoglossus hippoglossus and attempts to rear the larvae past first feeding. Mar Biol 7(3):99-107

Bolinches J, Egidius E (1987) Heterotrophic bacterial communities associated with the rearing of halibut Hippoglossus hippoglossus with special reference to Vibrio spp. J Appl Ichthyol 3:165-173

Bowden TJ, Lester K, MacLachlan P, Bricknell IR (2000) Preliminary study into the short term effects of adjuvants on Atlantic halibut (Hippoglossus hippoglossus L.) Bull Eur Assoc Fish Pathol 20(3):148-152

Bricknell IR, Bowden TJ, Bruno DW, MacLachlan P, Johnstone R, Elllis AE (1999) Susceptibility of Atlantic halibut Hippoglossus hippoglossus (L.) to infection with typical and atypical Aeromonas salmonicida. Aquaculture 175: $1-13$

Bristow G (1990) Dødelighet hos kveitelarver og yngel i startforingsfasen. Norsk Fiskeoppdrett 15:40-43

Canning EU, Lom J (1986) The microsporidian of vertebrates. Academic Press, London

Chilmonczyk S, Cox WT, Hedrick RP (1991) Enterocytozoon salmonis $\mathrm{n}$. sp.-an intranuclear microsporidium from salmonid fish. J Protozool 38:264-269

Dalmo RA, Seternes T, Arnesen SM, Jørgensen TØ, Bøgwald $\mathrm{J}$ (1998) Tissue distribution and cellular uptake of Aeromonas salmonicida lipopolysaccharide (LPS) in some marine fish species. J Fish Dis 21:321-334

Dalmo RA, Kjerstad AA, Arnesen SM, Tobias PS, Bøgwald J (2000) Bath exposure of Atlantic halibut (Hippoglossus hippoglossus L.) yolk sac larvae to bacterial lipopolysaccharide (LPS): absorption and distribution of the LPS and effect on fish survival. Fish Shellfish Immunol 10:107-128

Docker MF, Kent ML, Hervio DML, Khattra JS, Weiss LM, Devlin RH (1997) Ribosomal DNA sequence of Nucleospora salmonis Hedrick, Groff and Baxa, 1991 (Microsporea: Enterocytozoonidae): implications for phylogeny and nomenclature. J Eukaryot Microbiol 44:55-60

Elema MO, Hoff KA, Kristensen HG (1994) Multiple-dose pharmacokinetic study of flumequine in Atlantic salmon (Salmo salar L.). Aquaculture 128:1-11

Elema MO, Hoff KA, Kristensen HG (1995) Bioavailability of flumequine after oral administration to Atlantic salmon (Salmo salar L). Aquaculture 136:209-219

Elston RA, Drum S, Bunnell P (1995) Efficacy of orally administered Difloxacin for the treatment of furunculosis in atlantic salmon held in seawater. J Aquat Anim Health 7: $22-28$

Fuller R (1989) Probiotics in man and animals. J Appl Bacteriol 66:365-378

Gara B, Shields RJ, McEvoy L (1998) Feeding strategies to achieve correct metamorphosis of Atlantic halibut, Hippoglossus hippoglossus L., using enriched Artemia. Aquacult Res 29:935-948

Gatesoupe FJ (1999) The use of probiotics in aquaculture. Aquaculture 180:147-165

Gresoviac SJ, Khattra JS, Nadler SA, Kent M, Devlin RH Vivares CP, DeLaFuente E, Hedrick RP (2000) Comparison of small subunit ribosomal RNA gene and internal transcribed spacer sequences among isolates of the intranuclear microsporidian Nucleospora salmonis. J Eukaryot Microbiol 47:379-387

Grotmol S, Totland GK (2000) Surface disinfection of Atlantic halibut Hippoglossus hippoglossus eggs with ozonated sea-water inactivates nodavirus and increases survival of the larvae. Dis Aquat Org 39:89-96

Grotmol S, Totland GK, Kvellestad A, Fjell K, Olsen AB (1995) Mass mortality of larval and juvenile hatchery reared halibut Hippoglossus hippoglossus L. associated with the presence of virus-like particles in vacuolated lesions in the central nervous system and retina. Bull Eur Assoc Fish Pathol 15(5):176-180

Grotmol S, Totland GK, Thorud K, Hjeltnes BK (1997) Vacuolating encephalopathy and retinopathy associated with a nodavirus-like agent: a probable cause of mass mortality of cultured larval and juvenile Atlantic halibut Hippoglossus hippoglossus. Dis Aquat Org 29:85-97

Grotmol S, Bergh Ø, Totland GK (1999) Transmission of viral encephalopathy and retinopathy (VER) to yolk-sac larvae of the Atlantic halibut Hippoglossus hippoglossus: occurrence of nodavirus in various organs and a possible route of infection. Dis Aquat Org 36: 95-106

Grotmol S, Nerland AH, Biering E, Totland GK, Nishizawa T (2000) Characterisation of the capid protein gene from a nodavirus strain affecting the Atlantic halibut Hippoglossus hippoglossus and design of an optimal reversetranscriptase polymerase chain reaction (RT-PCR) detection assay. Dis Aquat Org 39:79-88

Hansen MK, Horsberg TE (1999) Single-dose pharmacokinetics of flumequine in halibut (Hippoglossus hippoglossus) 
and turbot (Scophtalmus maximus). J Vet Pharmacol Therapeutics 22:122-126

Hansen GH, Olafsen JA (1989) Bacterial colonisation of cod (Gadus morhua L.) and halibut (Hippoglossus hippoglossus L.) eggs in marine aquaculture. Appl Env Microbiol 55:1435-1446

Hansen GH, Bergh Ø, Michaelsen J, Knappskog D (1992) Flexibacter ovolyticus sp. nov., a pathogen of eggs and larvae of Atlantic halibut, Hippoglossus hippoglossus L. Int J Syst Bacteriol 42(3):451-458

Harboe T, Huse I, Øie G (1994a) Effects of egg disinfection on yolk sac and first feeding stages of halibut (Hippoglossus hippoglossus) larvae. Aquaculture 119:157-165

Harboe T, Tuene S, Mangor-Jensen A, Rabben H, Huse I (1994b) Design and operation of an incubator for yolk sac larvae of Atlantic halibut (Hippoglossus hippoglossus L.) Prog Fish-Cult 56:461-470

Harboe T, Mangor-Jensen A, Naas KE, Næss T (1998) A tank design for first feeding of Atlantic halibut, Hippoglossus hippoglossus L., larvae. Aquacult Res 29:919-923

Haug T (1990) Biology of the Atlantic halibut, Hippoglossus hippoglossus (L. 1758). Adv Mar Biol 26:1-69

Hedrick RP, Groff JM, McDowell TS, Willis M, Cox WT (1990) Hematopoetic intranuclear microsporidian infections with features of leukaemia in Chinook salmon Oncorhynchus tshawytscha. Dis Aquat Org 8:189-197

Helvik JV, Karlsen $\varnothing$ (1996) The effect of light- and darkrearing on the development of the eyes of Atlantic halibut (Hippoglossus hippoglossus) yolk-sac larvae. Mar Fresh Behav Physiol 28:107-121

Hjeltnes B, Bergh Ø, Wergeland H, Holm JC (1995) Susceptibility of Atlantic cod Gadus morhua, halibut, Hippoglossus hippoglossus and wrasse (Labridae) to Aeromonas salmonicida subsp. salmonicida and the possibility of transmission of furunculosis from farmed salmon Salmo salar to marine fish. Dis Aquat Org 23:25-31

Húsgarð S, Grotmol S, Hjeltnes BK, Rødseth OM, Biering E (2001) Immune response to a recombinant capsid protein of striped jack nervous necrosis virus (SJNNV) in turbot Scophthalmus maximus and Atlantic halibut Hippoglossus hippoglossus, and evaluation of a vaccine against SJNNV. Dis Aquat Org 45:33-44

Ingilæ M, Arnesen JA, Lund V, Eggset G (2000) Vaccination of Atlantic halibut Hippoglossus hippoglossus L., and spotted wolfish Anarhichas minor L., against atypical Aeromonas salmonicida. Aquaculture 183:31-44

Joosten PHM, Aviles-Trigueros M, Sorgeloos P, Rombout JHWM (1995) Oral vaccination of juvenile carp (Cyprinus carpio) and gilthead seabream (Sparus aurata) with bioencapsulated Vibrio anguillarum bacterin. Fish Shellfish Immunol 5:289-299

Kabata Z (1979) Parasitic copepoda of British fishes. The Ray Society, London

Kleinow KM, Jarboe HH, Shoemaker KE (1994) Comparative pharmacokinetics and bioavailability of oxolinic acid in channel catfish (Ictalurus punctatus) and rainbow trout (Oncorhynchus mykiss). Can J Fish Aquat Sci 51: 1205-1211

Køie M (1993) Aspects of the lifecycle and morphology of Hysterothylacium aduncum (Rudolphi, 1802) (Nematoda, Ascaroidea, Anisakidae). Can J Zool 71:1289-1296

Kvenseth AM, Pittman K, Helvik JV (1996) Eye development in Atlantic halibut (Hippoglossus hippoglossus): differentiation and development of the retina from early yolk stages through metamorphisos. Can J Fish Aquat Sci 53: $2524-2532$

Lom J, Dykova I (1992) Protozoa parasites of fishes. Dev
Aquat Fish Sci 26. Elsevier, Amsterdam

Mangor-Jensen A, Harboe T, Hennø J, Troland R (1998a) Design and operation of Atlantic halibut, Hippoglossus hippoglossus L., egg incubators. Aquacult Res 29:887-892

Mangor-Jensen A, Harboe T, Shields RJ, Gara B, Naas KE (1998b) Atlantic halibut, Hippoglossus hippoglossus L., larvae cultivation literature, including a bibliography. Aquacult Res 29:857-886

Martinsen B, Horsberg TE (1995) Comparative single-dose pharmacokinetics of four quinolones, oxolinic acid, flumequine, sarafloxacin and enrofloxacin in Atlantic salmon (Salmo salar) held in seawater at $10^{\circ} \mathrm{C}$. Antimicrob Agents Chemother 39:1059-1064

Martinsen B, Horsberg TE, Ingebrigtsen K, Gross IL (1994) Disposition of ${ }^{14} \mathrm{C}$-Sarafloxacin in Atlantic salmon Salmo salar, rainbow trout Oncorhynchus mykiss, cod Gadus morhua and turbot Scophthalamus maximus as demonstrated by means of whole-body autoradiography and liquid scintillation counting. Dis Aquat Org 18:37-44

Melby HP, Krogsrud J, Håstein T, Stenwig H (1991) All commercial salmon sea water farms in Norway harbour carriers of infectious pancreatic necrosis virus (IPNV) In: Fryer JL (ed) Proceedings of the 2nd International Symposium on Viruses of Lower Vertebrates. Oregon State University, Corvallis, p 211-217

Michel C, Gerard JP, Fourbet B, Collas R, Chevalier R (1980) Emploi de la flumequine contre la furunculose des salmonides: essais therapeutiques et perspectives pratiques. Bull Franc Piscicult 277:154-162

Morrison CM, MacDonald CA (1995) Normal and abnormal jaw development of the yolk-sac larva of Atlantic halibut Hippoglossus hippoglossus. Dis Aquat Org 22:173-184

Morrison CM, Martell DJ, Leggiadro C, O'Neil D (1996) Ceratomyxa drepanopsettae in the gallbladder of Atlantic halibut, Hippoglossus hippoglossus, from the northwest Atlantic Ocean. Folia Parasitol 43:20-36

Mortensen SH, Hjeltnes B, Rødseth OM, Krogsrud J, Christie KE (1990) Infectious pancreatic necrosis virus, serotype N1, isolated from Norwegian halibut (Hippoglossus hippoglossus), turbot, Scopthalmus maximus, and scallops (Pecten maximus). Bull Eur Assoc Fish Pathol 10:42

Munday BL, Nakai T (1997) Special topic review: nodaviruses as pathogens in larval and juvenile marine finfish. World $\mathrm{J}$ Microbiol Biotechnol 13:375-381

Naas KE, Næss T, Harboe T (1992). Enhanced first feeding of halibut larvae (Hippoglossus hippoglossus L.) in green water. Aquaculture 105:143-156

Næss T, Lie $\varnothing$ (1998) A sensitive period during first feeding for the determination of pigmentation pattern in Atlantic halibut, Hippoglossus hippoglossus L., juveniles: the role of diet. Aquacult Res 29:925-934

Næss T, Germain-Henry M, Naas KE (1995) First feeding of Atlantic halibut (Hippoglossus hippoglossus) using different combinations of Artemia or wild zooplankton. Aquaculture 130:235-250

Næss T, Harboe T, Mangor-Jensen A, Naas KE, Norberg B (1996) Successful first feeding of Atlantic halibut larvae from photoperiod-manipulated broodstock. Prog Fish-Cult 58:212-214

Nilsen F (1995) Description of Trichodina hippoglossi n. sp. from farmed Atlantic halibut larvae Hippoglossus hippoglossus. Dis Aquat Org 21:209-214

Nilsen F (2000) Small subunit ribosomal DNA phylogeny of microsporidia with reference to genera which infect fish. J Parasitol 86:128-133

Nilsen F, Bristow GA (1994) Microsporidosis in farmed Atlantic halibut larvae (Hippoglossus hippoglossus L.) due 
to Pleistophora sp. International Symposium on Aquatic Animal Health, Seattle, Washington 4-8 September, 1994 Nilsen F, Nylund A (1998) Identification of virus and parasites. In: Barnes AC, Davidson GA, Hindy MP, McIntosh D (eds) Methodology in fish diseases research, Aberdeen. Abbion Press, Aberdeen, p 227-240

Nilsen F, Ness A, Nylund A (1995) Observations on an intranuclear microsporidian in lymphoblasts from farmed halibut larvae (Hippoglossus hippoglossus L.) J Eukaryot Microbiol 42(2):131-135

Nilsen F, Endresen C, Hordvik I (1998) Molecular phylogeny of microsporidians with particular reference to species that infect the muscle of fish. J Eukaryot Microbiol 45: $529-537$

Nishizawa T, Furuhashi M, Nagai T, Nakai T, Muroga K (1997) Genomic classification of fish nodaviruses by phylogenetic analysis of the coat protein gene. Appl Environ Microbiol 63(4):1633-1636

Norberg B, Valkner V, Huse J, Karlsen I, Grung GL (1991) Ovulatory rhythms and egg viability in the Atlantic halibut (Hippoglossus hippoglossus). Aquaculture 97:365-371

Nordmo R, Holth Riseth JM, Varma KJ, Sutherland IH, Brokken ES (1998) Evaluation of florfenicol in Atlantic salmon, Salmo salar L.: efficacy against furunculosis due to Aeromonas salmonicida and cold water vibriosis due to Vibrio salmonicida. J Fish Dis 21:289-297

Opstad I, Bergh Ø (1993) Culture parameters and growth and mortality of halibut (Hippoglossus hippoglossus L.) yolk sac larvae in upwelling incubators. Aquaculture 109:1-11

Piaseki W, McKinnon BM (1995) Life cycle of a sea louse, Caligus elongatus von Nordmann, 1832 (Copepoda, Siphonostomatoida, Caligidae). Can J Zool 73:74-82

Pittman K, Skiftesvik AB, Harboe T (1989) Effect of temperature on growth ratesand organogenesis in the larvae of halibut (Hippoglossus hippoglossus L.) Rapp P-V Reun Cons Int Explor Mer 191:421-430

Pittman K, Bergh Ø, Opstad I, Skiftesvik AB, Skjolddal L, Strand H (1990a) Development of eggs and larvae of halibut (Hippoglossus hippoglossus L.). J Appl Ichthyol 6: $142-160$

Pittman K, Skiftesvik AB, Berg L (1990b) Morphological and behavioural development of halibut, Hippoglossus hippoglossus (L.) larvae. J Fish Biol 37:455-472

Pittman K, Jelmert A, Næess T, Harboe T, Watanabe K (1998) Plasticity of viable postmetamorphic forms of farmed Atlantic halibut, Hippoglossus hippoglossus L. Aquacult Res 29:949-954

Polyanskii YI (1955) Data on the parasitology of fishes from the northern seas of USSR. Parasites of the Barents Sea. Tr Zool Inst Akad Nauk SSSR 19:1-170

Reitan KI, Bolla S, Olsen Y (1994) A study of the mechanism of algal uptake in yolk-sac larvae of Atlantic halibut (Hippoglossus hippoglossus). J Fish Biol 44(2):303-310

Rødseth OM (1995) Sykdommer, parasitter og vaksiner. In: Pittman K, Berg L (eds) Kveite-fra forskning til næring. Kystnæringen Forlag og Informasjonskontor, Bergen, p 61-94 (in Norwegian)

Rogstad A, Ellingsen OF, Syvertsen C (1993) Pharmacokinetics and bioavailability of flumequine and oxolinic acid after various routes of administration to Atlantic salmon in seawater. Aquaculture 110:207-220

Rollefsen G (1934) The eggs and larvae of the halibut (Hippoglossus vulgaris). K Nor Vidensk Selsk Forh 7:20-23

Salvesen I, Vadstein O (1995) Surface disinfection of eggs from marine fish: evaluation of four chemicals. Aquacult Int 3:155-171

Salvesen I, Øie G, Vadstein O (1997) Surface disinfection of
Atlantic halibut and turbot eggs with glutaraldehyde: Evaluation of concentrations and contact times. Aquacult Int 5:249-258

Samuelsen OB (1997) Efficacy of bath administered flumequine and oxolinic acid in the treatment of vibriosis in halibut (Hippoglossus hippoglossus). J Aquat Anim Health 9:127-131

Samuelsen OB, Ervik A (1997) Single dose pharmacokinetic study of flumequine after intravenous, intraperitoneal and oral administration to Atlantic halibut (Hippoglossus hippoglossus) held in seawater at $9^{\circ} \mathrm{C}$. Aquaculture 158: 215-227

Samuelsen OB, Ervik A (1999) A single-dose pharmacokinetic study of oxolinic acid and vetoquinol, an oxolinic acid ester, in Atlantic halibut (Hippoglossus hippoglossus) held in seawater at $9^{\circ} \mathrm{C}$. J Fish Dis 22:13-23

Samuelsen OB, Lunestad BT (1996) Bath treatment, an alternative method for administration of the quinolones flumequine and oxolinic acid to halibut Hippoglossus hippoglossus, and in vitro antibacterial activity of the drugs against some Vibrio sp. Dis Aquat Org 27:13-18

Samuelsen OB, Lunestad BT, Jelmert A (1997a) Pharmacokinetic and efficacy studies on bath administering potentiated sulphonamides in Atlantic halibut, Hippoglossus hippoglossus L. J Fish Dis 20:287-296

Samuelsen OB, Hjeltnes B, Glette J (1997b) Efficacy of orally administered florfenicol in the treatment of furunculosis in Atlantic salmon. J Aquat Anim Health 10:56-61

Schram TA, Haug T (1988) Ectoparasites on the Atlantic halibut, Hippoglossus hippoglossus (L.) from northern Norway-potential pests in halibut aquaculture. Sarsia 73: $213-227$

Scott JS, Bray SA (1989) Helminth parasites of the alimentary tract of Atlantic halibut (Hippoglossus hippoglossus L) and Greenland halibut (Reinhardtius hippoglossoides Walbaum) on the Scotian shelf. Can J Zool 67:1476-1481

Shields RJ, Gara B, Gillespie MJS (1999). A UK perspective on intensive hatchery rearing methods for Atlantic halibut (Hippoglossus hippoglossus L.) Aquaculture 176:15-25

Skiftesvik AB, Bergh $\varnothing$ (1993) Changes in behaviour of halibut (Hippoglossus hipoglossus) and turbot (Scophthalmus maximus) yolk sac larvae induced by bacterial infections. Can J Fish Aquat Sci 50(12):2552-2557

Stoffregen DA, Chako AJ, Backman S, Babish JG (1993) Successful theraphy of furunculosis in Atlantic salmon, Salmo salar L., using the fluoroquinolone antimicrobial agent enrofloxacin. J Fish Dis 16:219-228

Strand HK, Dalmo RA (1997) Absorption of immunomodulating $\beta(1,3)$-glucan in yolk sac larvae of Atlantic halibut, Hippoglossus hippoglossus (L.). J Fish Dis 20:41-49

Svendsen YS, Haug T (1991) Effectiveness of formalin, benzocaine and hypersaline exposures against adults and eggs of Entobdella hippoglossi (Mueller) an ectoparasite on Atlantic halibut (Hippoglossus hippoglossus L.). Laboratory studies. Aquaculture 94:279-289

Tilseth S (1990) New marine fish species for cold-water farming. Aquaculture 85:235-245

Totland GK, Grotmol S, Morita Y, Nishioka T, Nakai T (2000) The pathogenicity of nodavirus strains from striped jack Pseudocaranx dentex and Atlantic halibut Hippoglossus hippoglossus studied by waterborne challenge of yolk-sac larvae of both teleost species. Dis Aquat Org 38:169-175

Urawa S, Ueki N, Karlsbakk E (1998) A review of Ichthyobodo infection in marine fishes. Fish Pathol 33:311-320

Vadstein O, Øie G, Olsen Y, Salvesen I, Skjermo J, SkjåkBræk G (1993) A strategy to obtain microbial control during larval development of marine fish. In: Reinertsen $\mathrm{H}_{\text {, }}$ 
Dahle LA, Jørgensen L, Tvinnereim K (eds) Proceedings of the 1st Intrnational Conference on Fish Farm Technology. Balkema, Rotterdam, p 69-75

van der Heiden MHT, Keukens HJ, van den Nieuwboer WHFX, Mengelers MJB, Boon JH (1994) Plasma disposition of flumequine in common carp (Cyprinus carpio L., 1758), African catfish (Clarias gariepinus Burchell, 1822) and European eel (Anguilla anguilla L., 1758) after a single per oral administration. Aquaculture 123:21-30

van der Meeren T (1995) Feed consumption and gut evacuation in Atlantic halibut (Hippoglossus hippoglossus L.) larvae. In: Lavens P, Jaspers E, Roelants I (eds) Larvi'95 Fish and Crustacean Larviculture Symposium, Ghent, Belgium, September 1995, p 381-384 EAS Spec Publ No. 24 van der Meeren T (2000) Oppdrett av kveite (Aquaculture of halibut) In: Karlsen Ø, Mangor-Jensen A (eds) Havbruksrapport 2000-fisken og havet særnummer 3-2000 ISN 0802 0620. Institute of Marine Research, Bergen, p 38-48

Editorial responsibility: Otto Kinne (Managing Editor), Oldendorf/Luhe, Germany van der Meeren T, Naas KE (1997) Development of rearing techniques using enclosed ecosystems in the mass production of marine fish fry. Rev Fish Sci 5:367-390

Wiik R, Hoff KA, Andersen K, Daae FL (1989) Relationships between plasmids and phenotypes of presumptive strains of Vibrio anguillarum isolated form different fish species. Appl Environ Microbiol 55:826-831

Wiik R, Stackebrandt E, Valle O, Daae FL, Rødseth OM, Andersen K (1995) Classification of fish pathogenic vibrios based on comparative 16S rRNA analysis. Int J Syst Bacteriol 45:421-428

Wiklund T, Dalsgaard I (1998) Occurrence and significance of atypical Aeromonas salmonicida in non-salmonid and salmonid fish species: a review. Dis Aquat Org 32:49-69

Wongtavatchai J, Conrad PA, Hedrick RP (1995) Effect of the microsporidian Enterocytozoon salmonis on the immune response of Chinook salmon. Vet Immunol Immunopathol 48:367-374

Submitted: March 3, 2001; Accepted: July 8, 2001 Proofs received from author(s): December 5, 2001 